Malahov A.

Palagin A., Maslov I., Gudilko R.

\title{
IMPROVEMENT OF SHIP BALLASTING SYSTEM
}

Досліджено прощес баластування суден, що задіяні для транспортування нестандартних вантажів, при їх експлуатащії на хвилюванні. При аналізі процесу баластування розглянуті теоретичні методи та результати моделювання руйнування повітряних об'ємів в воді. Встановлено, що видалення повітря при певних умовах може позитивно впливати на процес хитавиці судна призводячи до поліпшення його експлуатащійних характеристик.

Ключові слова: надлишкове повітря, баластна вода, корпус судна, ударні струмені, хитавиия судна.

\section{Introduction}

Current trends in the development of water transport used to transport large-size and non-standard cargoes on ships of the submerged type require the use of new approaches to the technology of their operation. First of all, there are requirements to increase the reliability of their work on excitement and reduce the time for carrying out loading and unloading operations without reducing the accident rate.

Specific features of the design of such ships during acceptance or delivery operations always lead to the same problem - the emergence and further chaotic movement of air cavities inside the ballast water tanks filled with water.

Due to the large volume of such cavities, their inertial characteristics during movement within the volume of the liquid can lead to increased list of the ship. They also give high additional loads on the ship's hull and can lead to emergencies with a negative outcome - loss of cargo, ship flooding, etc.

With this in mind, a very urgent scientific and technical task is required in the work of its solution, which consists in developing new principles for the operation of technical systems of submersible ships. These principles should ensure a significant improvement in the quality of operation of ships by using a new system for eliminating excess air from the working volumes of ballast tanks and reducing accidents associated with the additional list of the ship.

\section{The object of research and its technological audit}

The object of research is the process of flooding or floating of submerged ships in conditions of sea surface disturbance. The main problems that arise during such process are associated with maintaining the ship's trim. The only technical technique in this case is a combined combination of preliminary and basic ballasting operations. In the course of their carrying out, the ship's trim and list change is continuously made, which is connected with filling the numbers of specific tanks of the ship in a clear sequence and with a certain filling speed.

To reveal the specifics of this process from the point of view of changing the uncontrolled list of the ship, a technological audit is conducted. Its main purpose is determination of the influence degree of parasitic air volumes floating on the surface of ballast water on the loads that arise on the hull of the ship and uncontrolled angles of heel that arise when the ship is operating on waves.

The study is carried out on the basis of ballast tanks of the double bottom and the technological scheme of ballast pumps of the Target ship of the Dockwise-Boskalis company (Holland). As the main measuring equipment used Taylor Hobson Ultra autocollimator (UK), ultrasonic level sensors Mobrey 003 Ultrasonic Level Switch of Emerson company (USA), digital stopwatch and deformation sensors of ship control system OCTOPUS (Holland).

The technological scheme of the location of the tanks on the Target ship is shown in Fig. 1.

Observations of the filling process during the three voyages of the ship make it possible to state that the average degree of their fullness is always unequal since only $60-70 \%$ of the tanks are completely filled.

Differences in the residual volumes of water in the filled ballast tanks can lead to non-compliance with the ship's trim and the deterioration of its stability when it is in a fully submerged state.

With the full filling of tanks, there is almost always the appearance of parasitic air volumes in the form of air bubbles continuously moving along the water surface in the tank. The maximum value of their volumes can reach up to $10 \%$ of the total tank volume and range from 360 to $672 \mathrm{~m}^{3}$. Their movement in the ballast tanks during the list of the ship invariably leads to its uncontrollable additional list and increases the likelihood of an accident. It should be specially noted that the amplitude and direction of the parasitic air bubble inside the tank are in no way related to the characteristics of sea surface disturbance or wind load on the ship's hull and are spontaneous. The actual conditions for the onset of resonance leading to a ship's overturn always remain undefined. 


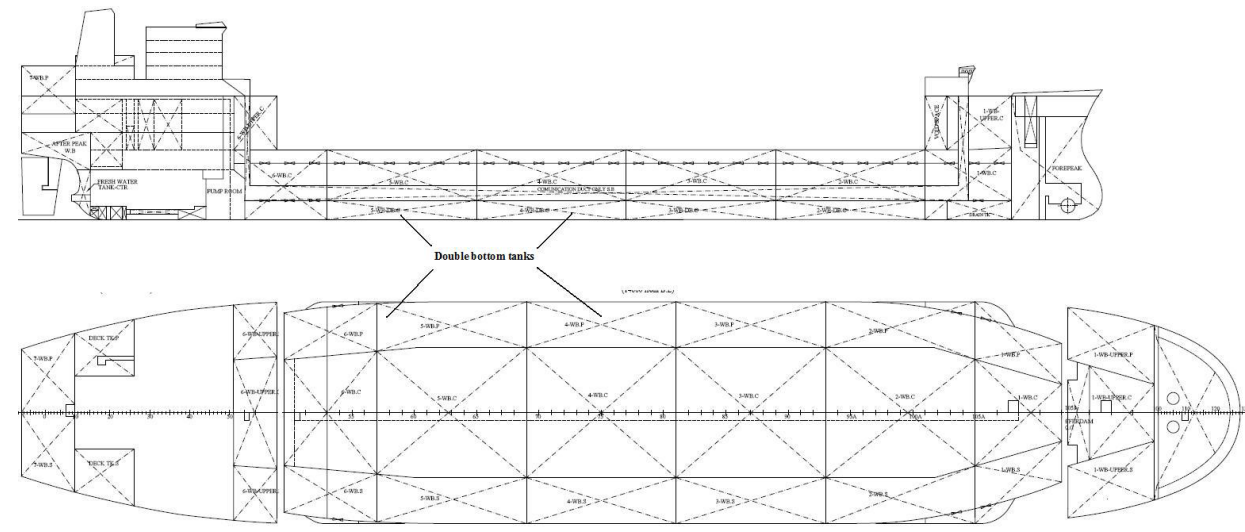

Fig. 1. Location of double bottom tanks on the Target ship

\section{The aim and objectives of research}

The aim of research is increase in the efficiency of the work and increase in the operational characteristics of submersible ships by developing a new technology for eliminating excessive parasitic air volumes in ship technological tanks.

To achieve this aim it is necessary:

1. To develop a new technology for supplying shock jets for destroying large parasitic air jams in the ship's ballast tanks.

2. To establish the main factors affecting the places of accumulation of parasitic air volumes in ballast tanks.

3. To study the regularities of the process of changing the uncontrolled list of a ship on waves in the case of using the developed technology of destruction of a parasitic air moving in a ballast tank.

\section{Research of existing solutions of the problem}

Among the main directions associated with the movement of gas bubbles in confined volumes with rigid boundaries, identified in the resources of the world scientific periodicals, can be singled out:

- moving gas clusters in liquids [1-3];

- floating of single bubbles in liquids [4-7];

- dispersion of gas jets in liquids [8-13].

In application to the problem of destruction of parasitic air volumes inside the ship's ballast holds, the investigations of [1, 2] most closely correspond. The main conditions for the destruction of gas volumes in liquids are shown in [1], and a classification of water-moving structured elements from a one-component gas is proposed in [2]. However, these works do not describe the mechanism or method of destruction of such gas volumes on the surface of water and do not show the conditions for the effect of their movement on the inertial characteristics of the fluid as a whole. Similarly, in [8] and [12] only the mechanical equilibrium of a gas volume in a liquid and the appearance of characteristic hydrodynamic structures near it are considered. At the same time, the movement of large volumes of air in water is not considered anywhere under the condition of dynamic impact from the walls of the ship in which they are located.

The results of the analysis allow to conclude that theoretical or experimental results have not yet been obtained unambiguously indicating how to destroy large gas volumes in liquids. Also, it is not established how they change the inertial properties of a liquid limited by the rigid walls of the ship. In connection with the technical features of the work of ships and the process of destruction of air bubbles in the ship's ballast tanks, the choice of the most suitable technical solution should be based on data obtained during field studies. Full-scale research should be carried out in the conditions of a real ship operating at sea surface disturbance.

\section{Methods of research}

In the conditions of the ship's operation, the experiments are limited by the technical conditions of its current operation. For this reason, as the main performance indicators of the developed system of destruction of parasitic air volumes in the ballast tanks of the ship, an uncontrolled angle of its list and the time of full filling of the tanks are chosen. These two parameters can be considered as indicators of the effectiveness of the ballasting process.

Input variables of the process - the degree of filling of the ballast tank, the volume and location of the parasitic air volume in relation to the walls of the ship's tank, as well as sea surface excitement are determined using automated measuring instruments. The sampling of experimental data is formed in a single file of the ship's control system OCTOPUS.

The first three variables are measured by a set of ultrasonic level sensors with a statistical processing of their output by the ship's control system OCTOPUS, and current data on the sea surface disturbance came from the shipboard control system CARGOMASTER (Holland).

Output variables of the process - uncontrolled list of the ship and the time of tank filling are also measured in automatic mode. The list is measured with an autocollimator with an error and the stability of the measurement of the angles throughout the tuned range is 0.2 seconds. The filling time of the ballast tank is measured using a digital stopwatch. The beginning of the process is recorded by the signal for the opening of the ballast bilge valve, and the end at the time the upper air valve was activated for overflow.

A complete description of the standard procedure can be found, for example, in [14].

The main provisions of the methodology described in this work are: 
- the beginning and the end of measurements should always be synchronized with the beginning and the end of the process of ballasting of ship tanks;

- all indications of the measuring equipment must be reset before the beginning of each series of measurements;

- the conditions for carrying out the measurements in each series of experiments should be identical in composition and temperature of the ballast water, the flow-pressure characteristics of the ballast pumps and the used stroke pressure in the jets;

- it is always necessary to perform a measurement of all changes in the list angle of the ship after stabilizing the autocollimator readings.

\section{Research results}

The results of measuring the reduction in the uncontrolled angle of the ship's list when using the system for destroying parasitic air volumes in the ship's central ballast tanks are shown in Fig. 2, 3.

Attention is drawn to the fact that:

- in the case of a very small sea surface disturbance (up to $0.2 \mathrm{~m}$ ), changes in both the natural and controlled list of the ship are completely subject to a linear law. The difference in the angles of the uncontrolled list of the ship at the maximum wave height of $0.2 \mathrm{~m}$ is only 0.012 degrees;

- at a wave height of 0.2 to $0.3 \mathrm{~m}$, a transition zone is observed when the angle difference of the uncontrolled list is, with a maximum wave height of $0.3 \mathrm{~m}$, a value of only 0.075 degrees;

- with an average wave of the sea surface, when the wave height lies in the range from 0.3 to $0.5 \mathrm{~m}$. The operation of the stabilization system begins to have a positive effect on the ship's stability. In the case of a maximum wave of $0.5 \mathrm{~m}$, the difference between the angles of uncontrolled list during system operation and without it is already 0.2 degrees;

- when the sea surface is strongly excited, when the wave height is in the range from 0.56 to $1 \mathrm{~m}$, the list difference between the two measurement options is constantly increasing. Thus, at a wave height equal to $0.56 \mathrm{~m}$, the maximum difference in the uncontrolled angles of the ship's list is 0.5 degrees, and at a wave height of 1 meter it is equal to 1.05 degrees. As a percentage, this difference in angles is $52.38 \%$.

The four curves in Fig. 2 are obtained by statistical processing of measurement results. They are a quality nomogram of the ship's list stabilization system by removing parasitic air volumes from ship's ballast tanks.

As a result of a comprehensive assessment of all the measurements of the ship's behavior on the waves, the efficiency of the developed system for eliminating air congestion inside the ballast tanks is checked. One of the main criteria for the effectiveness and quality of the system's operation can be the level of uncontrolled ship's list with the full filling of the central ballast tanks during the sinking of the ship's deck to the level of the sea surface.

To quantify the effect of the attached mass of air volumes inside the tanks on the stability of the ship with and without the operation of the stabilization system, it is found that:

- when the surface of the sea is equal to $0.5 \mathrm{~m}$, the level of uncontrolled list of the ship during the immersion in water is reduced from 2 to 1.5 degrees;

- the filling time for $100 \%$ of the volume of ballast tanks, when the system is operating, decreased by $12 \%$ compared with the time of the standard operation for filling;

- according to the OCTOPUS and CARGOMASTER systems, it is found that when the ship is ballasted, loads on its hull during the operation of the system are reduced by $3.4 \%$ compared to a conventional dive.

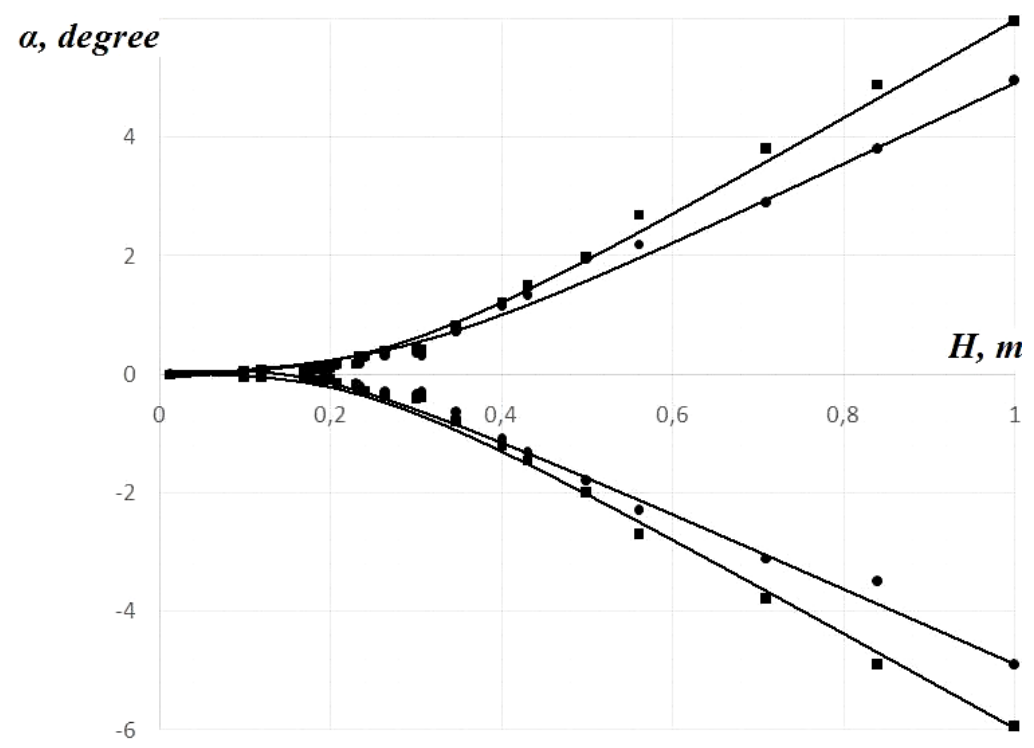

Fig. 2. Uncontralled angle of the ship's list at sea wave level in the range from $H=0.1 \mathrm{~m}$ to $H=1 \mathrm{~m}$ : - - work of the ship without the system; - - work of the ship with the system

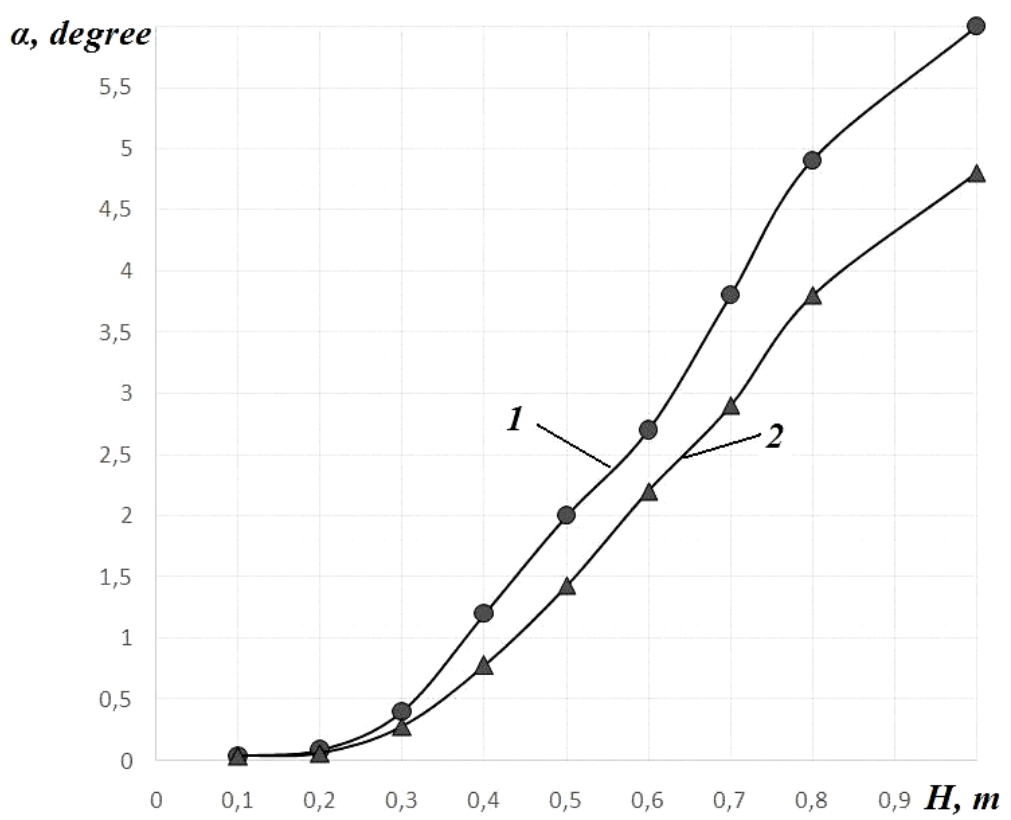

Fig. 3. Effectiveness evaluation of the system for eliminating air congestion: 1 - work of the ship without the system; 2 - work of the ship with the system 
The adequacy of the obtained data is evaluated by evaluating their confidence interval of reproducibility in different operating conditions of the ship and by comparing the measurement data with the results of the operation of the sensors of the OCTOPUS and CARGOMASTER ship control systems.

The analysis of the obtained results (Fig. 2) allows to draw a conclusion about the good quality of the work developed during the research of jet technology for the destruction of parasitic air volumes directly in the process of ballasting of the ship's tanks.

\section{SWOT analysis of research results}

Strengths. Among the strengths of this research, it is necessary to note the results obtained from the main operational parameters of the submerged ship - uncontrolled list angle and the time of full filling of shipboard ballast tanks. In favor of this statement are the above results of the ship's list in a wide range of sea surface excitement. It is for this reason that it is very difficult to choose the correct mode of changing its trim and heeling in practical operating conditions during diving or floating. The use of the obtained data with respect to the effect of sea surface disturbance on the uncontrolled ship's list allows to solve the problem of choosing a rational rate of change in the draft of the ship. Criteria for the control process are the initial amount of parasitic air in the ballast tanks of the ship and the level of sea surface disturbance.

Weaknesses. The weaknesses of this research are related to the fact that the proposed solutions on ships can technically be implemented only if there is a compressor system in their technological circuits. Such system must create shock air jets.

At the same time, a significant increase in the reliability of such operational characteristics of the ship as controllability and stability and, as a consequence, a reduction in its accident rate imposes special circumstances on the companies that manage them. In other words, such subjective factor, as additional costs for the modernization of the ship's ballast circuit, can become a priority in the future operation of the ship on the waves.

Opportunities. Additional opportunities to achieve the aim of research are the ever growing market for large-tonnage shipments of non-standard and bulky cargo. The submerged ships are widely used throughout the world. Despite significant differences in their overall dimensions primarily in the area of the deck and tonnage, these ships differ in the versatility of their design. This circumstance can be considered stimulating in the sense that the construction of ships of this class should be carried out taking into account the research results of the developed ballasting system of the ship. It is in this way that the problem of reducing the accident rate of submersible ships can be solved under the conditions of operation of almost any particular ship.

Threats. The threats in implementing the research results are related to the following main factors:

- the process of ballasting the ship is different in the case when the cargo is present on the deck and when it is not present. It is necessary to carry out additional studies on the effect of sailing objects on the deck on the resulting contribution to the unguided ship's list in both variants of carrying out loading and unloading operations;
- in the absence of a compressor system on the ship to produce air with increased pressure, modernization of the ship requires substantial use of labor and material resources. This, in turn, can be a significant limitation for the management of shipping companies.

Thus, SWOT analysis of research results allows to identify the main directions for the successful achievement of the research objective. Among them:

- the need to use the developed ballasting system for all submersible ships;

- introduction of the automation node of the developed system as a software unit;

- use of the algorithm of combined operation of the developed system with the ship systems OCTOPUS and CARGOMASTER.

\section{Conclusions}

1. It is investigated that when moving inside a ballast tank a large parasitic airlock, and, correspondingly, the mass of water behind it, the problem arises of increasing its attached mass. This will invariably lead to an increase in the uncontrolled angle of the ship's list.

There is a simple and reliable way to eliminate the negative consequences of this movement. This method consists in separating the airlock into a series of small and separated air bubbles. It is also possible to destroy it completely at the final stage of ballasting of the ship's tanks.

2. It is established that the operation of the system has a positive effect on the uncontrolled ship's list. When the surface of the sea is disturbed by $0.5 \mathrm{~m}$, the angle of the ship's list is reduced. At the beginning, ship's list at normal nominal dive is 2 degrees. When the ship is submerged with the operation of the system for destroying the parasitic air inside the ballast tanks, it became equal to 1.5 degrees.

3 . It is shown that from the height of the wave exceeding the value of $0.35 \mathrm{~m}$, the developed ballasting system of the ship brings a significant contribution to improving the accident-free operation of the ship.

In numerical terms, the level of uncontrolled ship's list on waves with a working system of destruction of the parasitic air volume and without it is different. At a wave height of $0.3 \mathrm{~m}$ to 0.12 degrees, with a wave height of $0.6 \mathrm{~m}$ to 0.65 degrees, and at $1 \mathrm{~m}$ to 1.2 degrees.

\section{References}

1. Massey, B. Mechanics of Fluids [Text] / B. Massey, J. WardSmith. - Ed. 7. - CRC Press, 1998. - 744 p.

2. Li, J. Euler-lagrange simulation of flow structure formation and evolution in dense gas-solid flows [Text] / J. Li. - Enschede: University of Twente, 2002. - 212 p.

3. Chashechkin, Yu. D. Fluxes and Structures in Fluids -2003 [Text] / ed. by Yu. D. Chashechkin, V. G. Baydulov // Processing of International Conference «Fluxes and Structures in Fluids», St. Petersburg, Russia, June 23-26, 2003. - Moscow: Institute for Problems in Mechanics of the RAS, 2004. - $250 \mathrm{p}$.

4. Taylor, R. Multicomponent Mass Transfer [Text] / R. Taylor, R. Krishna. - New York: John Wiley\&Sons Inc., 1993. - 618 p.

5. Meshkov, D. E. Issledovanie vliianiia obiema vsplyvaiushchego puzyria na harakter techeniia [Text] / D. E. Meshkov, E. E. Meshkov, V. S. Sivolgin // Vestnik Sarovskogo FizTeha. - 2005. No. 8. - P. 68-73.

6. Briuhanov, O. N. Teplomassoobmen [Text] / O. N. Briuhanov, S. N. Shevchenko. - Moscow: Infra-M, 2012. - 464 p.

7. Landau, L. D. Teoreticheskaia fizika [Text]. Vol. 6. Gidrodinamika / L. D. Landau, E. M. Lifshits. - Ed. 3. - Moscow: Nauka, 1986. - 736 p. 
8. White, F. M. Fluid Mechanics (Mechanical Engineering) [Text] F. M. White. - Ed. 8. - McGraw-Hill, 2015. - 864 p.

9. Khalypa, V. M. Tekhnichna mekhanika ridyny i hazu [Text] V. M. Khalypa, S. O. Vambol, I. V. Mishchenko, O. V. Prokopov. - Kharkiv: NUTsZU, 2012. - 224 p.

10. Currie, I. G. Fundamental Mechanics of Fluids [Text] I. G. Currie. - Ed. 4. - CRC Press, 2012. - 603 p.

11. Richardson, J. F. The evaporation of two-component liquid mixtures [Text] / J. F. Richardson // Chemical Engineering Science. - 1959. - Vol. 10, No. 4. - P. 234-242. doi:10.1016/00092509(59)80058-0

12. Lavrentev, M. A. Problemy gidrodinamiki i ih matematicheskie modeli [Text] / M. A. Lavrentev, B. V. Shabat. - Moscow: Nauka, 1973. - 416 p.

13. Chorin, A. J. A Mathematical Introduction to Fluid Mechanics [Text] / A. J. Chorin, J. E. Marsden // Texts in Applied Mathematics. - Springer US, 1990. - 168 p. doi:10.1007/9781-4684-0364-0

14. Malahov, A. V. Jet forces analysis for cones [Text] / A. V. Malahov, O. V. Streltsov, I. Z. Maslov, R. G. Gudilko // Proceedings of the 1st International Academic Conference «Science and Education in Australia, America and Eurasia: Fundamental and Applied Science». - Melbourne: IADCES Press, 2014. Vol. I. - P. 111-115.

\section{СОВЕРШЕНСТВОВАНИЕ СУДОВОЙ СИСТЕМЫ БАЛЛАСТИРОВКИ}

Исследован процесс балластировки судов, используемых для транспортировки нестандартных грузов, при их эксплуатации на волнении. При анализе процесса балластировки рассмотрены теоретические методы и результаты моделирования разрушения воздушных объемов в воде. Установлено, что удаление воздуха при определенных условиях может положительно влиять на процесс качки судна, приводя к улучшению его эксплуатационных характеристик.

Ключевые слова: избыточный воздух, балластная вода, корпус судна, ударные струи, качка судна

Malakhov Aleksey, Doctor of Physical and Mathematical Sciences, Professor, Department of Theory and Design of the Ship named after Prof. Yu. L. Vorobyov, Odessa National Maritime University, Ukraine, e-mail: a_malahov@yahoo.com, ORCID: http:// orcid.org/0000-0002-5003-8715

Palagin Alexander, Postgraduate Student, Department of Marine Auxiliary Machinery, National University «Odessa Maritime Academy»,Ukraine, e-mail: apalagin113@gmail.com, ORCID: http:// orcid.org/0000-0002-6533-5894

Maslov Igor, PhD, Associate Professor, Department of Energy and Navigation of Ships, National University «Odessa Maritime Academy»,Ukraine, e-mail: igormslv@ukr.net, ORCID: http:// orcid.org/0000-0003-1759-6077

Gudilko Roman, Postgraduate Student, Department of Marine Auxiliary Machinery, National University «Odessa Maritime Academy», Ukraine, ORCID: http://orcid.org/0000-0002-3140-0096 